Cite this: Phys. Chem. Chem. Phys., 2011, 13, 5144-5149

\title{
Conversion of gaseous nitrogen dioxide to nitrate and nitrite on aqueous surfactants
}

\author{
Takashi Kinugawa, ${ }^{a}$ Shinichi Enami, ${ }^{b}$ Akihiro Yabushita, ${ }^{a}$ Masahiro Kawasaki, ${ }^{a}$ \\ Michael R. Hoffmann ${ }^{b}$ and Agustín J. Colussi ${ }^{*} b$
}

Received 13th August 2010, Accepted 7th January 2011

DOI: $10.1039 /$ c0cp01497d

The hydrolytic disproportionation of gaseous $\mathrm{NO}_{2}$ on water's surface $\left(2 \mathrm{NO}_{2}+\mathrm{H}_{2} \mathrm{O} \rightarrow \mathrm{HONO}+\mathrm{NO}_{3}^{-}+\mathrm{H}^{+}\right)(\mathrm{R} 1)$ has long been deemed to play a key, albeit unquantifiable role in tropospheric chemistry. We recently found that (R1) is dramatically accelerated by anions in experiments performed on aqueous microjets monitored by online electrospray mass spectrometry. This finding let us rationalize unresolved discrepancies among previous laboratory results and suggested that under realistic environmental conditions (R1) should be affected by everpresent surfactants. Herein, we report that $\mathrm{NO}_{2}(\mathrm{~g})$ uptake is significantly enhanced by cationic surfactants, weakly inhibited by fulvic acid (FA, a natural polycarboxylic acid) and anionic surfactants, and unaffected by 1-octanol. Surfactants appear to modulate interfacial anion coverage via electrostatic interactions with charged headgroups. We show that (R1) should be the dominant mechanism for the heterogeneous conversion of $\mathrm{NO}_{2}(\mathrm{~g})$ to HONO under typical atmospheric conditions throughout the day. The photoinduced reduction of $\mathrm{NO}_{2}$ into $\mathrm{HONO}$ on airborne soot might play a limited role during daytime.

\section{Introduction}

Nitrogen dioxide is largely produced in the atmospheric oxidation of the nitric oxide emitted by high-temperature combustion sources. Increasing amounts of primary $\mathrm{NO}_{2}$ are being released into urban air by vehicles fitted with carbon particulate abatement devices. ${ }^{1}$ In the standard photochemical smog mechanism, $\mathrm{NO}_{2}$ is photolyzed within minutes (R2) and regenerated in a circuitous cycle that produces $\mathrm{OH}$-radicals via the short-wavelength photolysis of ozone in the presence of water (R3). ${ }^{2,3}$ The conversion of $\mathrm{NO}_{2}$ to HONO along (R1) triggers instead an alternative cycle in which $\mathrm{OH}$-radicals are directly generated via $(\mathrm{R} 4)$. The large ratio of photolysis frequencies $J(\mathrm{HONO}) / J\left(\mathrm{O}_{3}\right) \approx 15,,^{4,5}$ actually makes $(\mathrm{R} 1)+(\mathrm{R} 4)$ part of a faster cycle than that proceeding through (R2) + (R3), particularly at high solar zenith angles. Also notice that if $\mathrm{NO}_{2}$ were exclusively consumed via (R1), the oxidation of volatile organic compounds (VOC) would take place without $\mathrm{O}_{3}$ production.

$$
\begin{gathered}
2 \mathrm{NO}_{2}+\mathrm{H}_{2} \mathrm{O}(\mathrm{l}) \rightarrow \mathrm{HONO}+\mathrm{NO}_{3}^{-}(\mathrm{aq})+\mathrm{H}^{+}(\mathrm{aq})(\mathrm{R} 1) \\
\mathrm{NO}_{2}+h \nu_{\lambda<400 \mathrm{~nm}}\left(+\mathrm{O}_{2}\right) \rightarrow \mathrm{O}_{3}+\mathrm{NO} \\
\mathrm{O}_{3}+h \nu_{\lambda<315 \mathrm{~nm}}\left(+\mathrm{H}_{2} \mathrm{O}\right) \rightarrow 2 \mathrm{OH}+\mathrm{O}_{2} \\
\mathrm{HONO}+h \nu_{\lambda<405 \mathrm{~nm}} \rightarrow \mathrm{OH}+\mathrm{NO}
\end{gathered}
$$

${ }^{a}$ Department of Molecular Engineering, Kyoto University, Kyoto 615-8510, Japan

${ }^{b}$ W. M. Keck Laboratories, California Institute of Technology, Pasadena, CA 91125,U.S.A.E-mail: ajcoluss@caltech.edu
The chemical consequences of its rapid photolysis suggest that the significance of $\mathrm{HONO}$ exceeds that expected from its relative low abundance: $\mathrm{f}-\mathrm{HONO}=[\mathrm{HONO}] /\left[\mathrm{NO}_{2}\right]<0.1 .^{2,6,7}$ Current tropospheric chemistry models indicate that ozone mixing ratios are about three times more sensitive to $\mathrm{HONO}$ than to $\mathrm{NO}_{2}$ inputs: $\partial\left[\mathrm{O}_{3}\right] / \partial[\mathrm{HONO}] \approx 3 \partial\left[\mathrm{O}_{3}\right] / \partial\left[\mathrm{NO}_{2}\right]{ }^{1}$

Despite much work, the sources of tropospheric HONO remain speculative. ${ }^{8-12}$ Field measurements consistently point to a dominant role for thermal (dark) heterogeneous reactions because f-HONO peaks at nighttime and is strongly, positively correlated with particulate matter, PM, and relative humidity, $\mathrm{RH}$, levels. ${ }^{2,8,13-19}$ Possible mechanisms include: (A) the reduction of $\mathrm{NO}_{2}(\mathrm{~g})$ by labile, surface-bound $\mathrm{H}$-atom donors ${ }^{9,20}$ (exothermic $\mathrm{H}$-atom transfers are possible from $\mathrm{X}-\mathrm{H}$ donors having low bond dissociation energies $\mathrm{BDE}(\mathrm{X}-\mathrm{H})<\mathrm{BDE}(\mathrm{ONO}-\mathrm{H})=79 \mathrm{kcal} \mathrm{mol}^{-1}$, such as those of $\beta$-bonds in free radicals), ${ }^{21,22}$ (B) the bimolecular disproportionation of $\mathrm{NO}_{2}$ on wet surfaces (R1). ${ }^{23}$ The large and lingering discrepancies (up to four orders of magnitude) (10,18,23-33 $^{-3}$ among laboratory measurements of $\mathrm{NO}_{2}$ uptake coefficients "on water", $\gamma_{\text {water, has turned attention to airborne particles that }}$ could support pathway (A), such as soot and dust. ${ }^{12,16,20,34-50}$ Since $\mathrm{HONO}$ emissions from soot exposed to $\mathrm{NO}_{2}$ decay rapidly in the dark ${ }^{51}$ and cease immediately after illumination, ${ }^{34,52}$ significant HONO production at nighttime still calls for a thermal process of type (B) that would operate throughout the day.

Schwartz et al., at variance with previously held assumptions, ${ }^{10}$ had found that the reactive dissolution of low-pressure $\mathrm{NO}_{2}(\mathrm{~g})$ 
on pure water follows second-order kinetics in $\left[\mathrm{NO}_{2}(\mathrm{~g})\right]$, has therefore a very low probability (about one in ten million $\mathrm{NO}_{2}$ /water collisions) and would not contribute significantly to HONO production on cloud or aerosol droplets under atmospheric conditions. ${ }^{26,53}$ "Catalysis" by reactive species, such as transition metal ions, various types of natural organic matter and iodide, was considered, ${ }^{32}$ but found to have minimal impact on (R1). ${ }^{26}$ Subsequent measurements of $\mathrm{NO}_{2}(\mathrm{~g})$ uptake by $\mathrm{NaCl}$-seeded droplets in a cloud chamber led to much larger (up to $10^{4}$ times) (R1) reaction probabilities. ${ }^{24,25}$ These conflicting results were ascribed to mass transfer artifacts, ${ }^{23,25}$ rather than to the obvious fact that cloud chamber droplets were $1-3 \mathrm{mM}$ aqueous $\mathrm{NaCl}$ rather than pure water and, hence, that the two studies were not strictly comparable. In the absence of a clear rationale for the discrepancy the notion that (R1) is too slow at (low) atmospheric $\mathrm{NO}_{2}$ concentrations eventually settled in the field. Since the free radical $\mathrm{NO}_{2}(\mathrm{~g})$ is efficiently trapped as radical anions $\mathrm{X}-\mathrm{NO}_{2}{ }^{-}$ ( $\mathrm{X}=\mathrm{Cl}^{-}, \mathrm{Br}$ ) on sodium halide salts, ${ }^{54}$ we reasoned that inert anions could catalyze (R1) "on water" by a heretofore unknown mechanism. $^{27}$

Our expectations were confirmed in experiments showing that $\mathrm{NO}_{3}{ }^{-}$generation on water microjets exposed to $<4 \mathrm{ppmv}$ $\mathrm{NO}_{2}(\mathrm{~g})$ markedly increases in the presence of common electrolytes. Measured $\mathrm{NO}_{2}$ uptake coefficients rise from $\gamma_{\text {water }} \approx 10^{-7}$ on deionized water to $\gamma_{\mathrm{X}} \approx 10^{-3}$ on $1 \mathrm{mM}$ $\mathrm{NaX}\left(\mathrm{X}=\mathrm{F}, \mathrm{Cl}, \mathrm{Br}\right.$, I and $\left.\mathrm{HSO}_{4}{ }^{-}\right){ }^{55,56}$ It became apparent that $(\mathrm{R} 1)$ rates were controlled by the capture of $\mathrm{NO}_{2}(\mathrm{~g})$ by interfacial anions. Since (R1) rates depend on interfacial anion coverages, they should be affected by relative humidity and the surface-active species normally present in environmental aqueous media. ${ }^{57-59}$ Herein, we report the results of experiments on the uptake of $\mathrm{NO}_{2}(\mathrm{~g})$ on aqueous $\mathrm{NaBr}$ microjets ${ }^{60}$ doped with diverse surfactants, and analyze the environmental implications of our results.

\section{Experimental}

In these experiments, aqueous microjets exposed to $\mathrm{NO}_{2}(\mathrm{~g}) / \mathrm{N}_{2}(\mathrm{~g})$ for $10-20 \mu \mathrm{s}$ are continuously monitored for nitrate $\left(\mathrm{NO}_{3}{ }^{-}\right.$, $m / z=62$ ) by online electrospray ionization mass spectrometry (ESI-MS). ${ }^{60-62}$ Aqueous solutions of known composition are injected (at $50 \mu \mathrm{L} \mathrm{min}^{-1}$ ) as a liquid microjet via an electrically grounded, pneumatic nozzle (bore diameter: $100 \mu \mathrm{m}$ ) into the spraying chamber of an ESI mass spectrometer (mass range $m / z \geq 50$ ) held at $1 \mathrm{~atm}, 293 \mathrm{~K}$ (Scheme 1). The fast nebulizer $\mathrm{N}_{2}$ gas shortly tears up the outer layers of the microjet into microdroplets carrying ion excesses of either sign. ${ }^{63-65}$ The kinetic energy delivered in this process not only overcomes liquid cohesion, but also electrostatic attraction among anions and cations. Microdroplets are thereby created possessing a statistical distribution of net charges centered at zero charge, as expected from the random fragmentation of an electrically neutral liquid. ${ }^{66}$ The excess charges carried by such microdroplets are necessarily confined to the surface by electrostatics, are not affected by solvent evaporation or by reaction with a neutral gas, and constitute the basic magnitude retrieved as signal intensities by mass spectrometry. Excess ions are

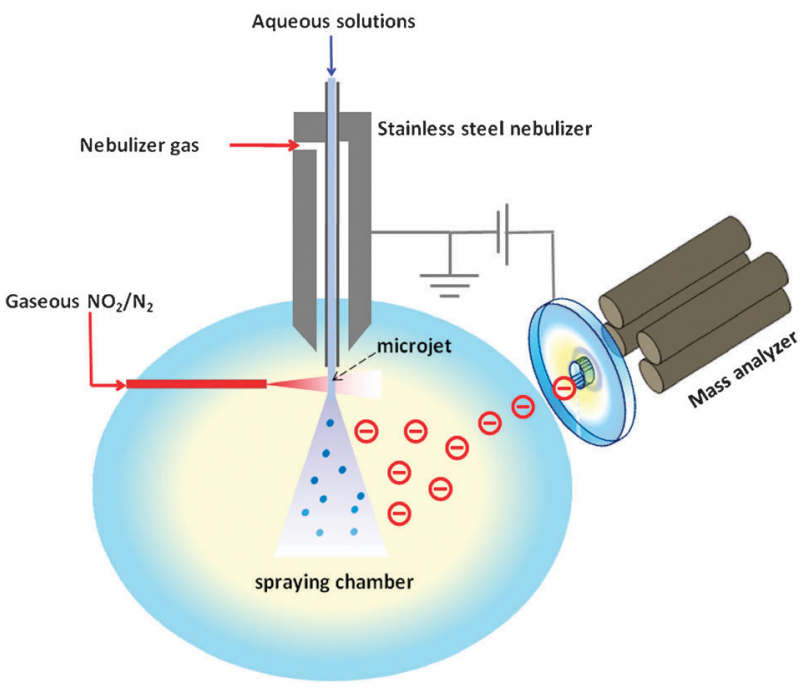

Scheme 1 A microjet is created in the spraying chamber of an electrospray mass spectrometer by injecting aqueous solutions through a grounded nebulizer. The microjet is briefly exposed to $\mathrm{NO}_{2}(\mathrm{~g}) / \mathrm{N}_{2}(\mathrm{~g})$ mixtures, whereupon $\mathrm{NO}_{3}{ }^{-}$is generated via (R1) on its outermost layers, before it is broken up by the fast nebulizer gas (at $\sim 10$ microseconds) into microdroplets carrying excess negative (including $\mathrm{NO}_{3}^{-}$) or positive charges. Upon subsequent solvent evaporation, the excess nitrate ions carried by the negatively charged microdroplets are ultimately ejected via field desorption, selected by an electrically biased inlet port, and detected by mass spectrometry within 1 millisecond.

ultimately ejected from the surface of rapidly evaporating microdroplets to the gas-phase as a result of electrical repulsion due to charge crowding, selected by an electrically biased inlet port, mass-analyzed and detected within 1 millisecond. ${ }^{67-69}$ The $\mathrm{NO}_{3}{ }^{-}$ESI-MS signal intensities detected in these experiments are therefore proportional to the amounts of $\mathrm{NO}_{3}{ }^{-}$ produced in the outermost layers of the microjet upon exposure to $\mathrm{NO}_{2}(\mathrm{~g}),{ }^{60}$ i.e., prior to its breakup into microdroplets. ${ }^{70} \mathrm{We}$ had verified that this setup actually behaves as a linear transfer device, i.e., ESI-MS signals are directly proportional to ion concentrations $(<2 \mathrm{mM})$ in the interfacial layers of the microjet. ${ }^{71,72}$ We have also demonstrated, and reported in the literature, that the products of gas/liquid reactions $\left(\mathrm{NO}_{3}{ }^{-}\right.$in this case) are formed and remain in the outermost layers of the liquid microjets for their ulterior detection by ESI-MS. ${ }^{60}$ Thus, for example, $\mathrm{Me}_{3} \mathrm{~N}(\mathrm{aq})$ is protonated in water below $\mathrm{pH}<\mathrm{p} K_{\mathrm{a}}\left(\mathrm{Me}_{3} \mathrm{NH}^{+}\right)=9.8$, whereas $\mathrm{Me}_{3} \mathrm{~N}(\mathrm{~g})$ can only be protonated on water of $\mathrm{pH}<4$. $^{60}$ The latter observation: (1) implies that $\mathrm{Me}_{3} \mathrm{~N}(\mathrm{~g})$ is protonated as $\mathrm{Me}_{3} \mathrm{NH}^{+}$(s) at the water's edge, (2) precludes prior $\mathrm{Me}_{3} \mathrm{~N}$ incursions into the bulk liquid, and (3) rules out subsequent $\mathrm{Me}_{3} \mathrm{NH}^{+}$(s) departures from the interfacial layers before being detected by ESI-MS. The significant and specific effects of added surfactants on the ESI-MS signal intensities detected in various studies performed in this setup represent additional evidence that the events monitored in these experiments actually take place at the air-water interface. ${ }^{56,70,72-76}$ $\mathrm{NO}_{2}$ concentrations in the chamber were calculated from $\mathrm{NO}_{2} / \mathrm{N}_{2}$ mixture flow rates as diluted by the $\mathrm{N}_{2}$ drying gas. Flow rates were regulated by mass flow controllers. Suwannee River fulvic acid (FA, Standard II, International Humic 
Substances Society), sodium bromide, 1-octanol (Fisher), tetrabutylammonium bromide $\left(\mathrm{TBA}^{+} \mathrm{Br}^{-}\right.$, Sigma-Aldrich), tetradecyltrimethylammonium bromide (TDTMA ${ }^{+} \mathrm{Br}^{-}$, Sigma-Aldrich) and potassium perfluorooctanesulfonate $\left(\mathrm{PFOS}^{-} \mathrm{K}^{+}, 3 \mathrm{M}\right)$ were used as received. All solutions were prepared in MilliQ water $(18.2 \mathrm{M} \Omega \mathrm{cm})$ from a Millipore Milli-Q gradient water purification system. Solutions $\mathrm{pH}$ was adjusted by adding $\mathrm{HCl} / \mathrm{NaOH}$ and measured with a calibrated $\mathrm{pH}$-meter.

\section{Results and discussion}

Online negative ion ESI mass spectra $(m / z \geq 50)$ of the species ejected from deionized water microjets exposed to up to $15 \mathrm{ppmv}$ $\mathrm{NO}_{2}(\mathrm{~g})\left(3.8 \times 10^{14}\right.$ molecules $\left.\mathrm{cm}^{-3}\right)$ display signals that are within noise levels (Fig. 1A and B). ${ }^{55}$ This observation implies that $(\mathrm{R} 1)$ generates $<0.1 \mu \mathrm{M} \mathrm{NO}_{3}{ }^{-}\left(<6 \times 10^{13}\right.$ ions $\mathrm{cm}^{-3}$, the sensitivity threshold) under such conditions. From the surface density, $\mathrm{S}\left(\mathrm{NO}_{3}{ }^{-}\right)$, of the $\mathrm{NO}_{3}^{-}$produced via (R1) in a liquid layer of thickness $\delta$ during $\mathrm{NO}_{2}(\mathrm{~g})$ collisions on deionized water microjets, eqn (E1): ${ }^{77}$

$$
\mathrm{S}\left(\mathrm{NO}_{3}{ }^{-}\right)=\delta\left[\mathrm{NO}_{3}{ }^{-}\right]=(1 / 4) \gamma_{\mathrm{w}} c \tau\left[\mathrm{NO}_{2}(\mathrm{~g})\right] / 2
$$

(where $\delta \approx 5 \times 10^{-8} \mathrm{~cm}, \gamma_{\text {water }}$ is the $\mathrm{NO}_{2}(\mathrm{~g}$ ) uptake coefficient on water, $c=3.72 \times 10^{4} \mathrm{~cm} \mathrm{~s}^{-1}$ is the mean speed of $\mathrm{NO}_{2}$ molecules at $300 \mathrm{~K}$, and $\tau>10 \mu \mathrm{s}$ is a lower bound to $\mathrm{NO}_{2}(\mathrm{~g}) /$ microjets contact time $)^{60}$ we estimate $\gamma_{\text {water }}<2 \times 10^{-7}$, which is in the upper range of previous results for the uptake of $\mathrm{NO}_{2}(\mathrm{~g})$ on neat water obtained by several independent techniques. 23,78

Similar experiments on $1 \mathrm{mM} \mathrm{NaBr}$ microjets led instead to significant $\mathrm{NO}_{3}{ }^{-}$production. Fig. $1 \mathrm{~A}$ and $\mathrm{B}$ show the intensities of $\mathrm{NO}_{3}{ }^{-}$ESI-MS signals (in linear and semilogarithmic scales, respectively) determined on microjets containing $1 \mathrm{mM}$ $\mathrm{NaBr}$ plus either $300 \mathrm{mg} \mathrm{L}^{-1} \mathrm{FA}, 1 \mathrm{mM} \mathrm{PFOS}^{-} \mathrm{K}^{+}, 1 \%$ 1-octanol, $1 \mathrm{mM} \mathrm{TBA}^{+} \mathrm{Br}^{-}$or TDTMA ${ }^{+} \mathrm{Br}^{-}$, at $\mathrm{pH} \approx 7$, as functions of $\left[\mathrm{NO}_{2}(\mathrm{~g})\right]$. It is apparent that: (1) the amounts of $\mathrm{NO}_{3}{ }^{-}$produced on these solutions are $>500$ times larger than on deionized water, (2) $\mathrm{NO}_{3}{ }^{-}$production increases linearly with $\left[\mathrm{NO}_{2}(\mathrm{~g})\right]$ below 5 ppmv, (3) ionic surfactants have significant effects, both promoting and inhibiting the catalytic action of $\mathrm{Br}^{-}$on (R1). At $\left[\mathrm{NO}_{2}(\mathrm{~g})\right]<5$ ppmv, $\left[\mathrm{N}_{2} \mathrm{O}_{4}\right] /\left[\mathrm{NO}_{2}\right]=$ $K_{\text {Dimerization }}\left[\mathrm{NO}_{2}\right]=2.5 \times 10^{-19} \mathrm{~cm}^{3}$ molecule ${ }^{-1}$ $\left[\mathrm{NO}_{2}\right]<3 \times 10^{-5}$, i.e., the contribution of $\mathrm{N}_{2} \mathrm{O}_{4}$ to these processes should be negligible, in accord with the linear increase of $\mathrm{NO}_{3}{ }^{-}$signal intensities with $\left[\mathrm{NO}_{2}(\mathrm{~g})\right]$. These findings reconcile the slow $\mathrm{NO}_{2}(\mathrm{~g})$ dissolution rates measured in pure water at Brookhaven ${ }^{30,79} v$ s. the much faster rates determined at Berkeley on seeded clouds consisting of $\sim 3 \mathrm{mM} \mathrm{NaCl}$ droplets. ${ }^{24}$ The exceedingly low probability of reaction (R1) on pure water is in accord with MD calculations showing that the hydrophobic free radical $\mathrm{NO}_{2}$ has strong propensity for the surface of neutral clusters $\mathrm{NO}_{2}\left(\mathrm{H}_{2} \mathrm{O}\right)_{n} \cdot{ }^{80}$ We infer that anions capture the 17-electron $\pi$-radical $\mathrm{NO}_{2}(\mathrm{~g})$ at the air/water interface via charge transfer into its semi-occupied molecular orbital, ${ }^{54}$ rather than by catalyzing $\mathrm{NO}_{2}$ (aq) disproportionation in the bulk phase.

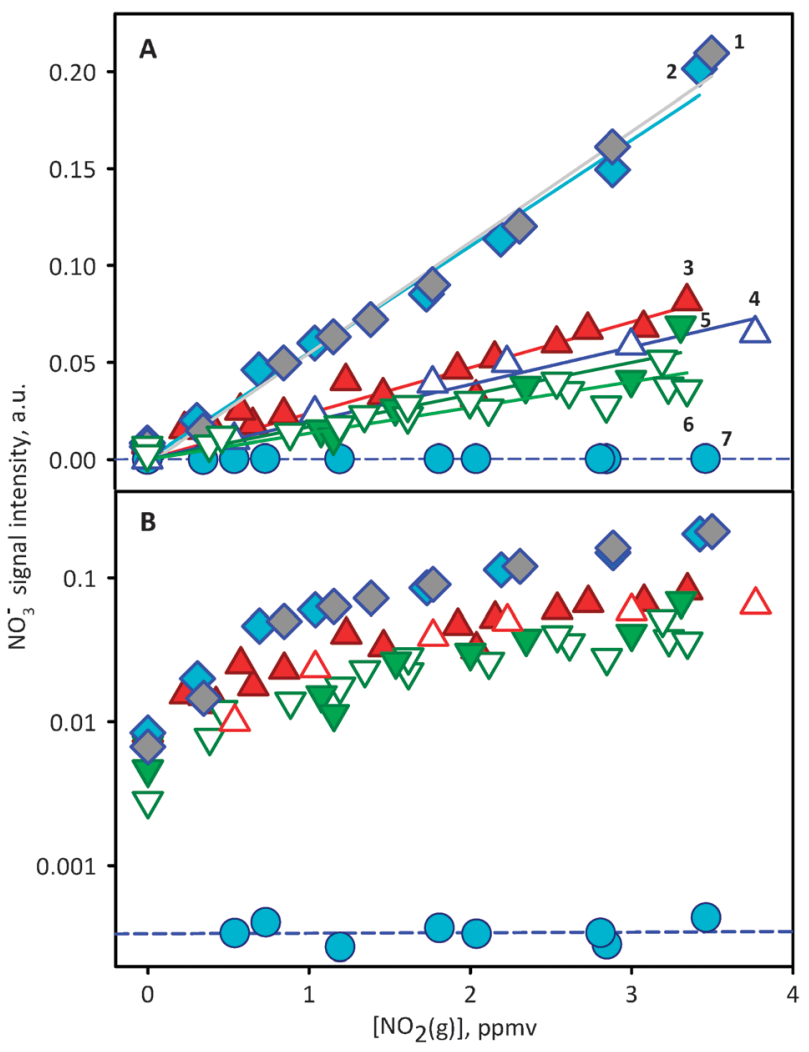

Fig. 1 ESI-MS $\mathrm{NO}_{3}{ }^{-}(m / z=62)$ signal intensities from aqueous microjets containing: (1) $1 \mathrm{mM}$ TDTMA ${ }^{+} \mathrm{Br}^{-}$(diamonds), (2) $1 \mathrm{mM}$ $\mathrm{TBA}^{+} \mathrm{Br}^{-}$(diamonds), (3) $1 \mathrm{mM} \mathrm{NaBr}$ (up-triangles), (4) $1 \mathrm{mM}$ $\mathrm{NaBr}+1 \% n$-octanol (open up-triangles), (5) $1 \mathrm{mM} \mathrm{NaBr}+$ $0.4 \mathrm{mM} \mathrm{PFOS}^{-} \mathrm{K}^{+}$(down-triangles), (6) $1 \mathrm{mM} \mathrm{NaBr}+300 \mathrm{mg} \mathrm{L}^{-1}$ fulvic acid (open down-triangles), (7) deionized $\mathrm{H}_{2} \mathrm{O}$ (circles), as functions of $\left[\mathrm{NO}_{2}(\mathrm{~g})\right]$. All experiments at $\mathrm{pH} \sim 7$.

The preceding observations are accounted for by the following mechanism:

$$
\begin{gathered}
\mathrm{X}^{-}+\mathrm{NO}_{2}(\mathrm{~g}) \stackrel{\text { slow }}{\longrightarrow}\left[\mathrm{X}-\mathrm{NO}_{2}^{--}\right]_{\text {interface }} \\
{\left[\mathrm{X}-\mathrm{NO}_{2}^{--}\right]_{\text {interface }}+\mathrm{NO}_{2}(\mathrm{~g})+\mathrm{H}_{2} \mathrm{O}} \\
\stackrel{\text { fast }}{\longrightarrow} \mathrm{X}^{-}+\mathrm{HONO}+\mathrm{NO}_{3}^{-}+\mathrm{H}^{+}
\end{gathered}
$$

in which $\mathrm{NO}_{2}(\mathrm{~g})$ disproportionates in two steps, reactions (R5) and (R6), through the intermediacy of persistent, interfacial $\mathrm{X}-\mathrm{N}_{2}{ }^{-}$radical anions. According to this mechanism, the overall rate of (R1) is controlled by the slow uptake of $\mathrm{NO}_{2}$ via (R5), followed by the rapid uptake of a second $\mathrm{NO}_{2}(\mathrm{~g})$ molecule via (R6) with a significantly higher probability. The catalytic role of anions in (R5) and (R6) has been clearly demonstrated in similar experiments in this setup, in which the enhanced production of $\mathrm{NO}_{3}{ }^{-}$in the presence of various $\mathrm{X}^{-}$is not accompanied by $\mathrm{X}^{-}$losses except in the case of $\mathrm{X}^{-}=\mathrm{I}^{-}$, in which it is partially oxidized to $\mathrm{I}_{2}{ }^{-}{ }^{-55} \mathrm{NO}_{2}(\mathrm{~g})$ uptake enhancement is therefore an example of general base catalysis. ${ }^{81}$

It should be realized that the oxidation of $\mathrm{NO}_{2}$ to $\mathrm{NO}_{3}{ }^{-}$ under the strictly anoxic conditions of our experiments can only occur via $\mathrm{NO}_{2}$ disproportionation (R1). Although $\mathrm{NO}_{2}{ }^{-}(m / z=46)$ falls outside the instrumental mass range 


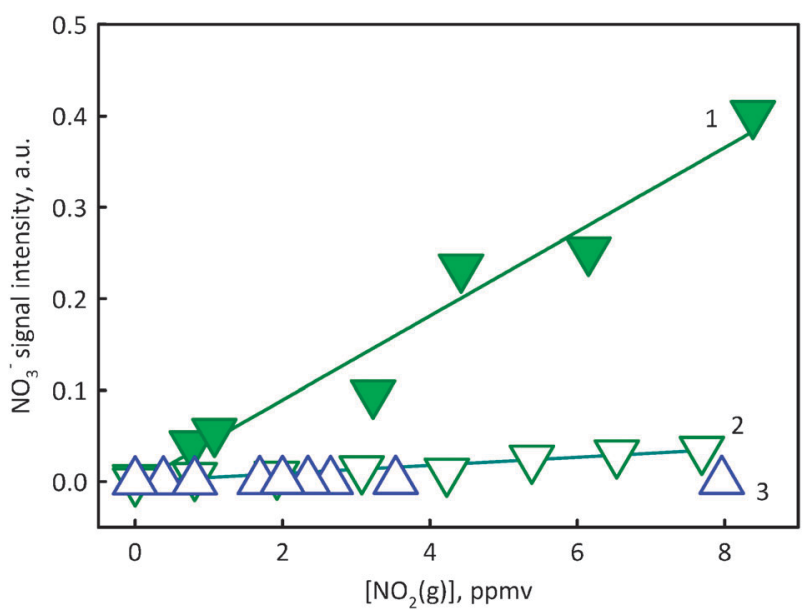

Fig. 2 ESI-MS nitrate signal intensities as a function of $\mathrm{NO}_{2}(\mathrm{~g})$ concentration on aqueous microjets containing: (1) $300 \mathrm{mg} \mathrm{L}^{-1}$ fulvic acid, (2) $0.8 \mathrm{mM} \mathrm{PFOS}^{-} \mathrm{K}^{+}$, (3) $1 \%$ (v/v) 1-octanol.

( $m / z \geq 50)$, it should have been possible to detect it as its cluster $\mathrm{Na}\left(\mathrm{NO}_{2}\right)_{2}{ }^{-}(m / z=115)$, had $\mathrm{NO}_{2}{ }^{-}$and $\mathrm{NO}_{3}{ }^{-}$been present at similar concentrations at the air/water interface. ${ }^{55}$ The absence of detectable $m / z=115$ signals therefore implies that neutral HONO $\left(\mathrm{p} K_{\mathrm{a}}=3.37\right)$ is largely released (whereas $\mathrm{HONO}_{2}$, whose $\mathrm{p} K_{\mathrm{a}}=-1.7$ ensures full dissociation to $\mathrm{NO}_{3}{ }^{-}+\mathrm{H}^{+}$, is not) to the gas phase.

The effect of the various surfactants is also consistent with an interfacial reaction catalyzed by anions. From the slopes of the linear plots of Fig. 1A we deduce that $\mathrm{NO}_{2}(\mathrm{~g})$ uptake on $1 \mathrm{mM} \mathrm{Br}^{-}$solutions is about 2.4 times larger for the surfactant $\mathrm{TDTMA}^{+}$and $\mathrm{TBA}^{+}$counterions than for $\mathrm{Na}^{+}$. In contrast, 1 mM FA (a suite of partially dissociated polycarboxylic acids, $\mathrm{p} K_{\mathrm{a}}$ 's from 2 to 8$)^{82}$ and $0.4 \mathrm{mM} \mathrm{PFOS}^{-}$depress $\mathrm{NO}_{2}(\mathrm{~g})$ uptake to $0.70 \times$ and $0.56 \times$ of their values in $1 \mathrm{mM} \mathrm{NaBr}$. $\mathrm{N}$-octanol, seemingly in line with the opposite effects of cationics and anionics, has no detectable effect on $\mathrm{NO}_{2}(\mathrm{~g})$ uptake. Fig. 2 shows that even in the absence of bromide, FA itself catalyzes (R1) whereas PFOS $^{-}$and 1-octanol do not. It appears that anions catalyze (R1) with efficiencies that increase with both increasing anion nucleophilicity and affinity for the air/water interface. Further elaboration is unwarranted at this time.

The combined effects of different anions on $\mathrm{NO}_{2}(\mathrm{~g})$ uptake may be additive at very low concentrations, but will compete for the interface above $\sim 1 \mathrm{mM}$. As a result, the much weaker nucleophile but better surfactant PFOS $^{-}$, by displacing $\mathrm{Br}^{-}$at the interface, effectively acts as an inhibitor. These considerations are supported by the data of Fig. 3, which show $\mathrm{NO}_{3}{ }^{-}$ production is an increasing linear function of ESI-MS $\mathrm{Br}^{-}$ signals, i.e., of interfacial $\mathrm{Br}^{-}$populations. ${ }^{83,84} \mathrm{We}$ conclude that the preponderantly anionic surfactants found in atmospheric aerosols ${ }^{58}$ should play a key role in the conversion of $\mathrm{NO}_{2}(\mathrm{~g})$ to $\mathrm{HONO}+\mathrm{NO}_{3}{ }^{-}$via $(\mathrm{R} 1)$. These observations further imply that the surfactant $\mathrm{TBA}^{+}$and $\mathrm{TDTMA}^{+}$counterions draw $\mathrm{Br}^{-}$closer to the interface, while the anionic FA and PFOS drag it away toward the bulk liquid. Since the hydrophobic alkyl chain of 1-octanol has no net effect on bromide-catalyzed $\mathrm{NO}_{3}{ }^{-}$production, ${ }^{85,86}$ we infer that electrostatic, rather than non-bonding interactions dominate these phenomena.

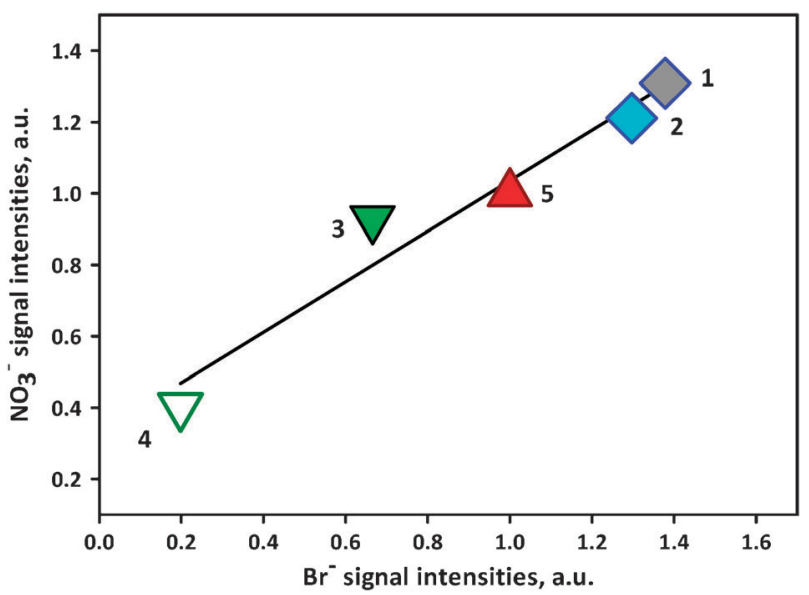

Fig. 3 ESI-MS nitrate versus bromide signal intensities on aqueous microjets exposed to 2 ppmv $\mathrm{NO}_{2}(\mathrm{~g})$ in the presence of (1) $1 \mathrm{mM}$ TDTMA $^{+} \mathrm{Br}^{-}$, (2) $1 \mathrm{mM} \mathrm{TBA}{ }^{+} \mathrm{Br}^{-}$, (3) $1 \mathrm{mM} \mathrm{NaBr}+300 \mathrm{mg} \mathrm{L}^{-1}$ fulvic acid, (4) $1 \mathrm{mM} \mathrm{NaBr}+0.8 \mathrm{mM} \mathrm{PFOS}^{-} \mathrm{K}^{+}$, (5) $1 \mathrm{mM} \mathrm{NaBr}$.

Amphiphilic molecules spontaneously segregate to the surface, and may eventually coat it with a monolayer film at sufficiently high concentrations. Gas-liquid scattering experiments have shown, however, that such films are not compact and may behave in diverse ways, which depend on molecular size and specific interactions. For example, $n$-hexanol films impose a barrier to the hydrolysis of $\mathrm{N}_{2} \mathrm{O}_{5}(\mathrm{~g})$, but are permeable to water evaporation and even enhance $\mathrm{HCl}(\mathrm{g})$ uptake. ${ }^{86,87}$ The fact that $n$-octanol and TDTMA $^{+}$do not inhibit (TDTMA $^{+}$ enhances) (R1) implies that their protruding alkyl chains do not hinder the access of the small $\mathrm{NO}_{2}(\mathrm{~g})$ molecules to the water's surface.

Rates of $\mathrm{NO}_{2}(\mathrm{~g})$ reactive dissolution in clouds and fogs consisting of aqueous electrolyte droplets can be calculated from: $R_{\mathrm{d}}=k_{\mathrm{d}}\left[\mathrm{NO}_{2}(\mathrm{~g})\right], k_{\mathrm{d}}=0.25 \gamma_{\mathrm{X}} c(S / V)_{\mathrm{w}}$, where $(S / V)_{\mathrm{w}}$ is the combined surface of aqueous droplets per volume of air. ${ }^{33,55}$ Typical $(S / V)_{\mathrm{w}}$ values vary from $<2 \times 10^{-5} \mathrm{~cm}^{-1}$ in clear weather to $>5 \times 10^{-5} \mathrm{~cm}^{-1}$ during foggy events. ${ }^{3,6,16,18}$ $(S / V)_{\mathrm{w}}$ and total electrolyte concentrations of typical cloud and fog droplets display, of course, wide variability spanning the 0.1 to $3 \mathrm{mM}$ range. ${ }^{88}$ Thus, by adopting a representative average value for the uptake coefficient of $\mathrm{NO}_{2}(\mathrm{~g})$ on tropospheric aerosols: $\gamma_{\mathrm{X}} \approx 1 \times 10^{-4}$, we estimate $k_{\mathrm{d}} \approx 2 \times 10^{-5} \mathrm{~s}^{-1}$, i.e., $\sim 7 \% \mathrm{NO}_{2}(\mathrm{~g})$ hourly conversions in clear-day conditions. These (necessarily) rough estimates are within the range of most field studies on HONO production both in urban and remote areas. This phenomenon would account for field measurements showing that $\mathrm{f}-\mathrm{HONO}$ reaches exceedingly large values $(\sim 0.3)$ on aerosols transported by winds proceeding from the sea, ${ }^{89}$ i.e., after they incorporate seawater electrolytes.

It can be shown that under typical conditions the photochemically-induced conversion of $\mathrm{NO}_{2}(\mathrm{~g})$ on soot particles is much slower than $(\mathrm{R} 1){ }^{12,41,42,52}$ Note that their relative rates should be proportional to $\left[\gamma_{\mathrm{X}}(S / V)_{\mathrm{w}}\right] /\left[\gamma_{\text {soot }}(S / V)_{\text {soot }}\right]$. A recent report gives $\gamma_{\text {soot }} \approx 2 \times 10^{-6}$ for stoichiometric flame soot exposed to $25 \mathrm{ppbv} \mathrm{NO}_{2}(\mathrm{~g})$ under solar irradiance $\left(1.48 \times 10^{15}\right.$ photons $\mathrm{cm}^{-2} \mathrm{~s}^{-1}$ between 300 and $\left.420 \mathrm{~nm}\right){ }^{34}$ From typical tropospheric airborne soot levels of $20 \mu \mathrm{g} \mathrm{C} \mathrm{m}^{-3}$ of air, ${ }^{3}$ by assuming $1 \mu \mathrm{m}$ radius particles of $\sim 2 \mathrm{~g} \mathrm{~cm}^{-3}$ 
density, we estimate $(S / V)_{\text {soot }} \approx 3 \times 10^{-7} \mathrm{~cm}^{-1}$. Thus, $\gamma_{\text {soot }}$ $(S / V)_{\text {soot }} \approx 6 \times 10^{-13} \mathrm{~cm}^{-1}$ is about three orders of magnitude smaller than $\gamma_{\mathrm{x}}(S / V)_{\mathrm{w}} \approx 2 \times 10^{-9} \mathrm{~cm}^{-1}$. Since the combined uncertainties and/or variations associated with the above estimates may not likely reverse the inequality $\left[\gamma_{\mathrm{X}}(S / V)_{\mathrm{w}}\right] /\left[\gamma_{\text {soot }}(S / V)_{\text {soot }}\right]>1$, we infer that $(\mathrm{R} 1)$ will dominate the atmospheric conversion of $\mathrm{NO}_{2}(\mathrm{~g})$ to $\mathrm{HONO}+\mathrm{NO}_{3}{ }^{-}$on atmospheric particles at all times.

Summing up, we show that: (1) f-HONO $=[\mathrm{HONO}] /\left[\mathrm{NO}_{2}\right]$ correlates with the product $\gamma_{\mathrm{X}} \times(S / V)_{\mathrm{w}}$ rather than with $(S / V)_{\mathrm{w}}$ alone, $^{13}$ (2) $\gamma_{\mathrm{X}}$ cannot be assumed to be constant, ${ }^{20}$ but will vary with the anion makeup of aerosol droplets. Thus, $\gamma_{\mathrm{X}}$ should depend on the sources and trajectory of air masses, and vary with relative humidity, i.e., with time of day, $, 98,80-93$ (3) the hydrolytic disproportionation of $\mathrm{NO}_{2}(\mathrm{~g})$ on aqueous aerosol droplets is deemed to be the main mechanism for the production of tropospheric HONO.

\section{Acknowledgements}

S. E. appreciates the Japan Society for the Promotion of Sciences Postdoctoral Fellowships for Research Abroad. This work was supported by National Science Foundation Grant ATM-0714329.

\section{References}

1 M. E. Jenkin, S. R. Utembe and R. G. Derwent, Atmos. Environ., 2008, 42, 323-336.

2 B. J. Finlayson-Pitts and J. N. Pitts, Chemistry of the upper and lower atmosphere, Academic Press, San Diego, CA, 2000.

3 J. H. Seinfeld and S. N. Pandis, Atmospheric chemistry and physics: from air pollution to climate change, Wiley, Hoboken, N.J., 2006.

4 S. P. Sander, R. R. Friedl, A. R. Ravishankara, D. M. Golden, C. E. Kolb, M. J. Kurylo, M. J. Molina, G. K. Moortgat, H. Keller, B. J. Finlayson-Pitts, P. H. Wine and R. E. Huie, Chemical Kinetics and Photochemical Data for Use in Atmospheric Studies, Evaluation Number 15, National Aeronautics and Space Administration, Jet Propulsion Laboratory, California Institute of Technology, Pasadena, California, 2006.

5 P. O. Wennberg and D. Dabdub, Science, 2008, 319, 1624-1625.

6 B. Aumont, F. Chervier and S. Laval, Atmos. Environ., 2003, 37, 487-498.

7 B. Alicke, U. Platt and J. Stutz, J. Geophys. Res., [Atmos.], 2002, 107, JD000075.

8 K. Acker, D. Beysens and D. Moller, Atmos. Res., 2008, 87, 200-212.

9 P. S. Monks, C. Granier, S. Fuzzi, A. Stohl, M. L. Williams, H. Akimoto, M. Amann, A. Baklanov, U. Baltensperger, I. Bey, N. Blake, R. S. Blake, K. Carslaw, O. R. Cooper, F. Dentener, D. Fowler, E. Fragkou, G. J. Frost, S. Generoso, P. Ginoux, V. Grewe, A. Guenther, H. C. Hansson, S. Henne, J. Hjorth, A. Hofzumahaus, H. Huntrieser, I. S. A. Isaksen, M. E. Jenkin, J. Kaiser, M. Kanakidou, Z. Klimont, M. Kulmala, P. Laj, M. G. Lawrence, J. D. Lee, C. Liousse, M. Maione, G. McFiggans, A. Metzger, A. Mieville, N. Moussiopoulos, J. J. Orlando, C. D. O'Dowd, P. I. Palmer, D. D. Parrish, A. Petzold, U. Platt, U. Poschl, A. S. H. Prevot, C. E. Reeves, S. Reimann, Y. Rudich, K. Sellegri, R. Steinbrecher, D. Simpson, H. ten Brink, J. Theloke, G. R. van der Werf, R. Vautard, V. Vestreng, C. Vlachokostas and R. von Glasow, Atmos. Environ., 2009, 43, 5268-5350.

10 S. E. Schwartz and W. H. White, Trace Atmospheric Constituents, Wiley, New York, 1983.

11 G. Lammel and J. N. Cape, Chem. Soc. Rev., 1996, 25, 361-369.

12 C. George, R. S. Strekowski, J. Kleffmann, K. Stemmler and M. Ammann, Faraday Discuss., 2005, 130, 195-210.
13 Y. Yu, B. Galle, A. Panday, E. Hodson, R. Prinn and S. Wang, Atmos. Chem. Phys., 2009, 9, 6401-6415.

14 J. Stutz, B. Alicke, R. Ackermann, A. Geyer, S. H. Wang, A. B. White, E. J. Williams, C. W. Spicer and J.D. Fast, J. Geophys. Res., [Atmos.], 2004, 109, JD004135.

15 K. Acker, D. Moller, W. Wieprecht, R. Auel, D. Kalass and W. Tscherwenka, Water, Air, Soil Pollut., 2001, 130, 331-336.

16 A. R. Reisinger, Atmos. Environ., 2000, 34, 3865-3874.

17 B. J. Finlayson-Pitts, Phys. Chem. Chem. Phys., 2009, 11, 7760-7779.

18 J. Notholt, J. Hjorth and F. Raes, Atmos. Environ., Part A, 1992, 26, 211-217.

19 R. Svensson, E. Ljungstrom and O. Lindqvist, Atmos. Environ., 1987, 21, 1529-1539.

20 J. Kleffmann, ChemPhysChem, 2007, 8, 1137-1144.

21 S. W. Benson, Thermochemical Kinetics, Wiley-Interscience, New York, 1976.

22 R. E. Huie, Toxicology, 1994, 89, 193-216.

23 S. E. Schwartz and Y. N. Lee, Atmos. Environ., 1995, 29, $2557-2559$.

24 A. Bambauer, B. Brantner, M. Paige and T. Novakov, Atmos. Environ., 1994, 28, 3225-3232.

25 T. Novakov, Atmos. Environ., 1995, 29, 2559-2560.

26 Y. N. Lee and S. E. Schwartz, J. Geophys. Res., [Atmos.], 1981, 86, 1971-1983.

27 R. M. Harrison and G. M. Collins, J. Atmos. Chem., 1998, 30, 397-406.

28 J. N. Cape, R. L. Storetonwest, S. F. Devine, R. N. Beatty and A. Murdoch, Atmos. Environ., Part A, 1993, 27, 2613-2621.

29 R. Karlsson and E. Ljungstrom, J. Aerosol Sci., 1995, 26, 39-50.

30 Y. N. Lee and S. E. Schwartz, J. Phys. Chem., 1981, 85, 840-848.

31 S. Mertes and A. Wahner, J. Phys. Chem., 1995, 99, 14000-14006.

32 T. Nash, J. Chem. Soc. A, 1970, 3023-3024.

33 J. Kleffmann, K. H. Becker and P. Wiesen, Atmos. Environ., 1998, 32, 2721-2729.

34 M. E. Monge, B. D’Anna, L. Mazri, A. Giroir-Fendler, M. Ammann, D. J. Donaldson and C. George, Proc. Natl. Acad. Sci. U. S. A., 2010, 107, 6605-6609.

35 V. H. Grassian, Int. Rev. Phys. Chem., 2001, 20, 467-548.

36 B. Aumont, S. Madronich, M. Ammann, M. Kalberer, U. Baltensperger, D. Hauglustaine and F. Brocheton, J. Geophys. Res., [Atmos.], 1999, 104, 1729-1736.

37 F. Arens, L. Gutzwiller, U. Baltensperger, H. W. Gaggeler and M. Ammann, Environ. Sci. Technol., 2001, 35, 2191-2199.

38 M. Ammann, M. Kalberer, D. T. Jost, L. Tobler, E. Rossler, D. Piguet, H. W. Gaggeler and U. Baltensperger, Nature, 1998, 395, 157-160.

39 M. Ammann, E. Rossler, R. Strekowski and C. George, Phys. Chem. Chem. Phys., 2005, 7, 2513-2518.

40 J. L. Ponche, C. George and P. Mirabel, J. Atmos. Chem., 1993, 16, $1-21$.

41 K. Stemmler, M. Ammann, C. Donders, J. Kleffmann and C. George, Nature, 2006, 440, 195-198.

42 K. Stemmler, M. Ndour, Y. Elshorbany, J. Kleffmann, B. D’Anna, C. George, B. Bohn and M. Ammann, Atmos. Chem. Phys., 2007, 7, 4237-4248.

43 J. M. Langridge, R. J. Gustafsson, P. T. Griffiths, R. A. Cox, R. M. Lambert and R. L. Jones, Atmos. Environ., 2009, 43, $5128-5131$.

44 K. Acker and D. Moller, Environ. Chem., 2007, 4, 242-255.

45 R. J. Gustafsson, G. Kyriakou and R. M. Lambert, ChemPhysChem, 2008, 9, 1390-1393.

46 R. J. Gustafsson, A. Orlov, P. T. Griffiths, R. A. Cox and R. M. Lambert, Chem. Commun., 2006, 3936-3938.

47 X. F. Wang, Y. P. Zhang, H. Chen, X. Yang, J. M. Chen and F. H. Geng, Environ. Sci. Technol., 2009, 43, 3061-3066.

48 G. Sarwar, S. J. Roselle, R. Mathur, W. Appel, R. L. Dennis and B. Vogel, Atmos. Environ., 2008, 42, 5760-5770.

49 R. Broske, J. Kleffmann and P. Wiesen, Atmos. Chem. Phys., 2003, 3, 469-474.

50 M. T. Cheng, S. P. Chen, Y. C. Lin, C. C. Jung and C. L. Horng, Environ. Eng. Sci., 2008, 25, 1149-1157.

51 R. Kurtenbach, K. H. Becker, J. A. G. Gomes, J. Kleffmann, J. C. Lorzer, M. Spittler, P. Wiesen, R. Ackermann, A. Geyer and U. Platt, Atmos. Environ., 2001, 35, 3385-3394. 
52 B. D’Anna, A. Jammoul, C. George, K. Stemmler, S. Fahrni, M. Ammann and A. Wisthaler, J. Geophys. Res., [Atmos.], 2009, 114, JD011237.

53 Y. N. Lee and S. E. Schwartz, J. Phys. Chem., 1981, 85, 840-848.

54 J. K. S. Wan, J. N. Pitts, P. Beichert and B. J. FinlaysonPitts, Atmos. Environ., 1996, 30, 3109-3113.

55 A. Yabushita, S. Enami, Y. Sakamoto, M. Kawasaki, M. R. Hoffmann and A. J. Colussi, J. Phys. Chem. A, 2009, 113, $4844-4848$.

56 S. Enami, M. R. Hoffmann and A. J. Colussi, J. Phys. Chem. B, 2009, 113, 7977-7981.

57 G. Kiss, B. Varga, A. Gelencser, Z. Krivacsy, A. Molnar, T. Alsberg, L. Persson, H. C. Hansson and M. C. Facchini, Atmos. Environ., 2001, 35, 2193-2200.

58 M. T. Latif and P. Brimblecombe, Environ. Sci. Technol., 2004, 38, 6501-6506.

59 W. Seidl and G. Hanel, Pure Appl. Geophys., 1983, 121, 1077-1093.

60 S. Enami, M. R. Hoffmann and A. J. Colussi, J. Phys. Chem. Lett., 2010, 1, 1599-1604.

61 S. Enami, M. R. Hoffmann and A. J. Colussi, Proc. Natl. Acad. Sci. U. S. A., 2008, 105, 7365-7369.

62 S. Enami, M. R. Hoffmann and A. J. Colussi, J. Phys. Chem. Lett., 2010, 1, 2374.

63 P. Kebarle and M. Peschke, Anal. Chim. Acta, 2000, 406, 11-35.

64 S. Nguyen and J. B. Fenn, Proc. Natl. Acad. Sci. U. S. A., 2007, 104, 1111-1117.

65 L. W. Zilch, J. T. Maze, J. W. Smith, G. E. Ewing and M. F. Jarrold, J. Phys. Chem. A, 2008, 112, 13352-13363.

66 E. E. Dodd, J. Appl. Phys., 1953, 24, 73-80.

67 J. B. Fenn, J. Am. Soc. Mass Spectrom., 1993, 4, 524-535.

68 J. B. Fenn, Angew. Chem., Int. Ed., 2003, 42, 3871-3894.

69 M. L. Nguyen, Y. Bedjanian and A. Guilloteau, J. Atmos. Chem., 2009, 62, 139-150.

70 S. Enami, M. R. Hoffmann and A. J. Colussi, J. Phys. Chem. B, 2008, 112, 4153-4156.

71 J. Cheng, E. Psillakis, M. R. Hoffmann and A. J. Colussi, J. Phys. Chem. A, 2009, 113, 8152-8156.

72 S. Enami, C. D. Vecitis, J. Cheng, M. R. Hoffmann and A. J. Colussi, J. Phys. Chem. A, 2007, 111, 8749-8752.

73 S. Enami, M. R. Hoffmann and A. J. Colussi, J. Phys. Chem. B, 2009, 113, 9356-9358.
74 S. Enami, M. R. Hoffmann and A. J. Colussi, J. Phys. Chem. A 2009, 113, 7002-7010.

75 S. Enami, M. R. Hoffmann and A. J. Colussi, Chem. Res. Toxicol., 2009, 22, 35-40.

76 S. Enami, C. D. Vecitis, J. Cheng, M. R. Hoffmann and A. J. Colussi, Chem. Phys. Lett., 2008, 455, 316-320.

77 P. Davidovits, C. E. Kolb, L. R. Williams, J. T. Jayne and D. R. Worsnop, Chem. Rev., 2006, 106, 1323-1354.

78 J. Kleffmann, K. H. Becker and P. Wiesen, J. Chem. Soc., Faraday Trans., 1998, 94, 3289-3292.

79 Y. N. Lee and S. E. Schwartz, J. Geophys. Res., [Atmos.], 1981, 86, 1971-1983.

80 D. S. Bezrukov and Y. V. Novakovskaya, Struct. Chem., 2004, 15, 77-81.

81 E. V. Anslyn and D. A. Dougherty, Modern Physical Organic Chemistry, University Science Books, Sausalito, California, 2006.

82 J. A. Leenheer, R. L. Wershaw and M. M. Reddy, Environ. Sci. Technol., 1995, 29, 399-405.

83 J. Cheng, M. R. Hoffmann and A. J. Colussi, J. Phys. Chem. B, 2008, 112, 7157-7161.

84 J. Cheng, C. D. Vecitis, M. R. Hoffmann and A. J. Colussi, J. Phys. Chem. B, 2006, 110, 25598-25602.

85 D. J. Donaldson and V. Vaida, Chem. Rev., 2006, 106, 1445-1461.

86 S. C. Park, D. K. Burden and G. M. Nathanson, Acc. Chem. Res., 2009, 42, 379-387.

87 D. K. Burden, A. M. Johnson and G. M. Nathanson, J. Phys. Chem. A, 2009, 113, 14131-14140.

88 A. Marinoni, P. Laj, K. Sellegri and G. Mailhot, Atmos. Chem. Phys., 2004, 4, 715-728.

89 M. Qin, P. H. Xie, H. Su, J. W. Gu, F. M. Peng, S. W. Li, L. M. Zeng, J. G. Liu, W. Q. Liu and Y. H. Zhang, Atmos. Environ., 2009, 43, 5731-5742.

90 W. Elbert, M. R. Hoffmann, M. Kramer, G. Schmitt and M. O. Andreae, Atmos. Environ., 2000, 34, 1109-1122.

91 K. F. Moore, D. E. Sherman, J. E. Reilly and J. L. Collett, Atmos. Environ., 2004, 38, 1389-1402.

92 K. F. Moore, D. E. Sherman, J. E. Reilly, M. P. Hannigan, T. Lee and J. L. Collett, Atmos. Environ., 2004, 38, 1403-1415.

93 A. Amoroso, H. J. Beine, G. Esposito, C. Perrino, M. Catrambone and I. Allegrini, Water, Air, Soil Pollut., 2008, 188, 81-92. 